\title{
Pandemi Covid-19 Sebagai Alasan Force Majeure Dalam Melakukan Pemutusan Hubungan Kerja di Indonesia ${ }^{{ }^{*}}$
}

\author{
Mustakim, ${ }^{2}$ Syafrida ${ }^{3}$ \\ Lecturer of Faculty of Law, Universitas Nasional \\ Lecturer of Faculty of Law, Universitas Tama Jagakarsa \\ 10.15408/sjsbs.v7i8.16552
}

\begin{abstract}
The fact of Corona Virus Disease 2019 (Covid-19) pandemics was often made as a reason by a lot of companies to conduct massive layoffs (PHK) in Indonesia. The regulation about force majeure to do massive layoffs (PHK) could only be found in Article 164 Act No. 13 Year 2003 about employment and it is not that specific about what kind of condition which could be categorized as force majeure that enables companies to conduct massive layoffs PHK. The statement of problem of this research is the spread of Covid-19 a condition categorized as force majeure that could become the reason to do a massive layoffs and how is the legal protection of worker toward the layoffs during the Covid-19 pandemics? This is normative research with constitutional and conceptual approach. The result from the observation and analysis indicated that the Covid-19 pandemics could be qualified as a force majeure but to conduct massive layoffs the companies need to experience loss or disadvantage and already closed permanently or massive layoffs is conducted for efficiency as what has been regulated by Article 164 point (1) and (3) Act No. 13 Year 2003 about employment by doing some steps in advance as stated in Minister Hand-outs No. SE-907/MEN/PHI-PPHI/X/2004, $28^{\text {th }}$ October 2004 and the decision of the Supreme Court No. 19/PUU-IX/2011, 20 th June 2012.
\end{abstract}

Keywords: Work relationship, massive layoffs, Covid-19

\begin{abstract}
ABSTRAK
Fakta penyebaran Corona Virus Disease 2019 (Covid-19) banyak dijadikan alasan bagi perusahaan-perusahaan untuk melakukan pemutusan hubungan kerja (PHK) d Indonesia. Pengaturan mengenai alasan force majeure dalam melakukan PHK hanya terdapat dalam Pasal 164 Undang-Undang No. 13 Tahun 2003 Tentang Ketenagakerjaan dan tidak terlalu rinci bagaimana kondisi yang dapat dikualifikasi sebagai force majeure sehingga perusahaan dapat melakukan PHK. Rumusan masalah penelitian ini adalah apakah penyebaran Covid19 merupakan kondisi yang dikualifikasi force majeure sehingga dapat dijadikan alasan untuk melakukan pemutusan hubungan kerja dan bagaimana perlindungan hukum pekerja atas pemutusan hubungan kerja yang terjadi pada masa penyebaran Covid-19 ? Penelitian ini menggunakan metode penelitian normatif dengan pendekatan perundang-undangan dan
\end{abstract}

*Diterima: 13 April 2020, Revisi: 22 Juli 2020, Diterbitkan 12 Agustus 2020.

${ }^{1}$ Tulisan ini dibuat sebagai bentuk keprihatinan karena banyaknya terjadi pemutusan hubungan kerja di berbagai perusahaan di Indonesia yang dilakukan pada saat Pandemi Cotona Virus Disease 2019

2 Mustakim adalah Dosen Tetap Fakultas Hukum Universitas Nasional dan Advokat pada Perhimpunan Advokat Indonesia/PERADI. Email : mustakim_adv@yahoo.com

${ }^{3}$ Syafrida adalah Dosen Tetap Fakultas Hukum Universitas Tama Jagakarsa. Email : syafrida_01@yahoo.com 


\begin{abstract}
konsep. Dari hasil penelusuran dan analisis dapat ditegaskan penyebaran Covid-19 dapat dikualifikasi sebagai keadaan memaksa namun untuk melakukan PHK perusahaan harus mengalami kerugian dan telah tutup secara permanen atau PHK dilakukan dengan alasan efisiensi sebagaimana diatur Pasal 164 ayat (1) dan (3) Undang-Undang No. 13 Taun 2003 Tentang Ketenagakerjaan dengan terlebih dahulu melakukan langkah-langkah dalam Surat Edaran Menteri Nomor SE-907/MEN/PHI-PPHI/X/2004, tertanggal 28 Oktober 2004 dan Putusan Mahkamah Konstitusi Nomor 19/PUU-IX/2011, tertanggal 20 Juni 2012.
\end{abstract}

Kata kunci : Hubungan Kerja, Pemutusan Hubungan Kerja, Covid-19

\title{
A. PENDAHULUAN
}

Dunia berduka tidak terkecuali Indonesia akibat penyebaran Corona Virus Disease atau sering dikenal dengan Covid-19 yang begitu cepat dan luas. World Health Organization (WHO) telah menetapkan Covid-19 sebagai pandemi global setelah menjangkiti lebih dari 118.000 orang dan menyebabkan kematian lebih dari 4.000 orang di 114 negara pada 11 Maret 2020. Pneumonia yang disebabkan oleh SARS-CoV 2 atau coronavirus ini menjadi ancaman serius bagi negara-negara di dunia karena sifat penyebarannya yang cepat. ${ }^{4}$

Data sementara dari situs resmi WHO pada pekan ketiga Maret 2020 menunjukkan kasus infeksi corona terkonfirmasi sebanyak 294.110 di 186 negara dan 12.944 di antaranya menyebabkan kematian. Negara dengan jumlah kasus Covid-19 terbanyak adalah China, Italia, Spanyol, Iran, Jerman, Amerika Serikat, dan Perancis. ${ }^{5}$

Penyebaran Covid-19 di tengah masyarakat turut memukul perekonomian negara Indonesia. Hampir semua sektor perekonomian nasional mengalami perlambatan. Bahkan ada kekhawatiran Covid-19 menyebabkan krisis ekonomi yang berujung pada pemutusan hubungan kerja (PHK) massal.

Data resmi dari Dinas Tenaga Kerja, Transmigrasi dan Energi (Nakertrans dan Energi) DKI Jakarta menyebutkan, sekitar 3.611 pekerja dari 602 perusahaan di Jakarta terkena PHK dan sesuai dengan Kepala Dinas Nakertrans dan Energi DKI Jakarta, Andri Yansyah mengatakan bahwa selain ada dikenai PHK juga terdapat 21.797 pekerja dan buruh di 3.633 perusahaan dirumahkan. ${ }^{6}$

Banyaknya PHK yang dilakukan perusahaan-perusahaan di Indonesia sebagai pilihan yang dilakukan oleh pelaku usaha untuk menekan pengeluaran perusahaan agar perusahaan dapat kembali stabil. ${ }^{7}$ PHK bagi pekerja merupakan sesuatu hal yang paling

${ }^{4}$ Radika Cahyadi, 5 Langkah Perusahaan Lindungi Karyawan dari Wabah Corona, Artikel tanggal 4 Maret 2020. Lihat di https:/www.gadjian.com/blog/2020/03/24/5-langkah-perusahaan-lindungikaryawan-dari-wabah-corona/

${ }^{5}$ Ibid.

6 jpnn.com, Jumlah Buruh Terkena PHK di Jakarta akibat Corona, Lumayan Banyak, Sabtu, 04 April 2020 - 18:17 WIB

${ }^{7}$ Bimo Prasetio dan Mohamad Toha Hasan, Dapatkah Perusahaan Melakukan PHK Karena Kerugian Akibat Pandemi Covid-19? bplawyers.co.id, 1 April, 2020. Dapat dilihat ulasan lengkapnya di https://bplawyers.co.id/2020/04/01/dapatkah-perusahaan-melakukan-phk-karena-kerugian-akibatpandemi-covid-19/ di unduh pada tanggal 4 April 2020. 
menakutkan ${ }^{8}$ Di satu pihak Wakil Ketua Komisi X DPR, Sri Rahayu mengatakan perlu antisipasi dan strategi yang tepat untuk mengantisipasi dampak penyebaran Covid-19 dan menyampaikan untuk menghindari jangan sampai dampak penyebaran Covid-19 menyebabkan PHK. ${ }^{9}$

Tulisan ini akan membahas masalah mengenai apakah penyebaran Covid-19 dapat dijadikan alasan keadaan memaksa (force majeure) dalam melakukan PHK dan bagaimanakah perlindungan hukum pekerja atas pemutusan hubungan kerja yang terjadi pada masa penyebaran Covid-19?

\section{B. METODE PENELITIAN}

Penelitian ini digolongkan ke dalam penelitian hukum normatif dilakukan dengan cara menelaah bahan kepustakaan atau bahan-bahan sekunder belaka".10 Penelitian normatif bertujuan untuk sistematisasi, mengkoreksi dan memperjelas aturan hukum yang berlaku pada bidang hukum tertentu dengan cara melakukan analisis terhadap teks yang bersifat autoritatif yang meliputi bahan hukum primer dan sekunder dan juga menemukan konsistensi dan kepastian hukum dan secara intensif mengevaluasi ketercukupan aturan-aturan hukum yang telah ada dan tujuannya adalah untuk memberikan rekomendasi dilakukannya perubahan terhadap kekurangan yang ditemukan dalam suatu aturan hukum tertentu (Reform Oriented Research). ${ }^{11}$

Pendekatan penelitian ini menggunakan Pendekatan undang-undang (statute approach), Pendekatan Konseptual (conceptual approach). Bahan Hukum Primer yaitu bahan hukum yang autoritatif artinya mempunyai otoritas ${ }^{12}$ berupa peraturan perundang-undangan Pasal 164 Undang-Undang No. 13 Taun 2003 Tentang Ketenagakerjaan (UUK), Kitab Undang-Undang Hukum Perdata (KUHPerdata). Dan Undang-Undang No. 2 tahun 2004 tentang Penyelesaian Perselisihan Hubungan Industrial (UU PPHI). Bahan hukum Sekunder yaitu bahan hukum yang memberikan petunjuk terhadap bahan hukum primer dan bahan tersier atau penunjang atau bahan non hukum.

Selanjutnya bahan hukum yang diperoleh dalam penelitian ini diuraikan dan dihubungkan sedemikian rupa, sehingga disajikan dalam penulisan yang lebih sistematis guna menjawab permasalahan yang telah dirumuskan. ${ }^{13}$

${ }^{8}$ Hubungan industrial pada dasarnya adalah proses terbinanya komunikasi, konsultasi, musyawarah dan berunding serta ditopang oleh kemampuan dan komitmen yang tinggi dari semua elemen yang ada di dalam perusahaan.

9 Bayu Hermawan, Legislator Ingatkan Dampak Corona Jangan Sampai Sebabkan PHK, Republika.co.id, Senin 09 Mar 2020 18:13 WIB di unduh pada tanggal 4 April 2020.

10 Soerjono Soekanto dan Sri Mamudji, Penelitian Hukum Normatif Suatu Tinjauan Singkat, (Jakarta, PT. RajaGrafindo, 2007), hlm.12-13.

${ }^{11}$ Diah Octorina Susanti dan A'an Effendi, Penelitian Hukum (Legal Research), cetakan 1 (Jakarta: Sinar Grafika, 2014), hlm. 11.hlm.12.

12 Ibid, hlm.141. hal. 393.

${ }^{13}$ Johnny Ibrahim, Teori E Metodologi Penelitian Hukum Normatif. (Jakarta: Bayumedia, 2006), 
Analisis bahan hukum dilakukan secara preskriptif analitis yaitu penalaran deduktif-induktif untuk menghasilkan figur hukum sebagai jawaban permasalahan atau temuan penelitian lainya dengan tujuan menghasilkan preskripsi apa yang seharusnya sebagai esensi dalam penelitian hukum. ${ }^{14}$ Hasil analisis dengan menggunakan logika hukum, argumentasi hukum, asas-asas hukum yang akan menghasilkan kesimpulan sebagai jawaban dari masalah yang harus dijawab serta digunakan penalaran hukum (legal reasoning).

\section{HASIL DAN PEMBAHASAN}

\section{Covid-19 sebagai Alasan Pemutusan Hubungan Kerja}

Hubungan Industrial Pancasila (HIP) adalah sistem hubungan yang terbentuk antara para pelaku dalam proses produksi barang dan jasa (pekerja, pengusaha dan pemerintah) yang didasarkan atas nilai-nilai yang merupakan manifestasi dan keseluruhan nilai-nilai Pancasila dan Undang-Undang Dasar Negara Republik Indonesia Tahun 1945 yang tumbuh dan berkembang di atas kepribadian bangsa dan kebudayaan nasional Indonesia. ${ }^{15}$

Prinsip Hubungan Industrial Pancasila yang dianut di Indonesia harus dipergunakan sebagai acuan dalam mengatasi atau memecahkan berbagai persoalan yang timbul dalam bidang ketenagakerjaan. Dalam Hubungan Industrial Pancasila, setiap keluh kesah yang terjadi di tingkat perusahaan dan masalah-masalah ketenagakerjaan lain yang timbul harus diselesaikan secara kekeluargaan atau musyawarah mencapai mufakat. ${ }^{16}$

Pasal 1 angka 25 UUK, menyebutkan bahwa Pemutusan Hubungan Kerja adalah pengakhiran hubungan kerja karena suatu hal tertentu yang mengakibatkan hubungan berakhirnya hak dan kewajiban antara pekerja/buruh dari pengusaha. ${ }^{17}$

PHK merupakan salah satu jenis perselisihan dalam hubungan Industrial. Istilah perselisihan hubungan Industrial sebelum keluarnya PPHI disebut perselisihan perburuhan. Terminologi hubungan Industrial merupakan istilah baru yang dilembagakan oleh UUK dan UU PPHI, sehingga perselisihan yang timbul antara Pekerja/Buruh ataupun antara Pengusaha atau Gabungan Usaha dengan Serikat Pekerja/Buruh atau Gabungan Serikat Pekerja/Buruh dinamakan Perselisihan Hubungan Industrial.

Menurut Pasal 1 angka 1 UUPHI, Perselisihan Hubungan Industrial adalah:

Perbedaan pendapat yang mengakibatkan pertentangan antara pengusaha atau gabungan pengusaha dengan pekerja/buruh atau serikat pekerja/serikat buruh karena

${ }^{14}$ Peter Mahmud Marzuki, Marzuki, Peter Mahmud, Penelitian Hukum, Cet. I, (Jakarta : Prenada Media, 2008), hal. 206. Lihat juga Amiruddin dan Zainal Asikin, Pengantar Metode Penelitian Hukum, (Jakarta : RajaGrafindo, 2016), hlm.172.

15 Zainal Asikin, Agusfian Wahab, Lalu Husni dan Zaeni Asyhadie, Dasar-Dasar Hukum Perburuhana, (Jakarta : RajaGrafindo Persada, 2008), hal. 238

${ }^{16}$ Lalu Husni, Loc.Cit.

${ }^{17}$ Ibid, 
adanya perselisihan hak, perselisihan kepentingan, perselisihan pemutusan hubungan kerja dan perselisihan antar serikat pekerja/serikat buruh dalam satu perusahaan. ${ }^{18}$

Menurut Pasal 1 angka 4 UUPHI, menjelaskan Perselisihan PHK adalah perselisihan yang timbul akibat tidak adanya kesesuaian pendapat mengenai pengakhiran hubungan kerja yang dilakukan oleh salah satu pihak (pengusaha dan pekerja).

PHK semaksimal mungkin harus dihindari karena memberikan dampak yang buruk tidak hanya pengusaha akan tetapi pekerja/buruh yang menerima dampak yang lebih buruk lagi. Ketentuan Pasal 151 ayat (1) UUK menegaskan bahwa bahwa pengusaha, pekerja/buruh, serikat pekerja/serikat buruh, dan pemerintah, dengan segala upaya harus mengusahakan agar jangan terjadi PHK. PHK dimungkinkan apabila memang kondisi hubungan kerja sudah tidak dapat diperbaiki dan sesuai dengan alasan dan cara-cara yang ditentukan Pasal 150 s/d 172 UUK.

Timbulnya dampak PHK kepada buruh dan keluarganya dijelaskan oleh Soepomo bahwa:

Pemutusan hubungan kerja bagi buruh merupakan permulaan dari segala pengakhiran, permulaan dan berakhirnya mempunyai pekerjaan, permulaan dan berakhirnya kemampuan membiayai keperluan hidup sehari-hari dan keluarganya, permulaan dan berakhirnya kemampuan menyekolahkan anak-anak dan sebagainya. ${ }^{19}$

Sebelum memberikan analisis pemutusan hubungan kerja dalam kondisi penyebaran Covid-19 terlebih dahulu harus ditegaskan bahwa apakah kondisi penyebaran Covid-19 di Indonesia dapat dikatakan sebagai keadaan force majeure. Istilah keadaan memaksa berasal dari bahasa Inggris, yaitu force majeure, atau dalam bahasa Belanda disebut dengan overmacht. Keadaan memaksa adalah suatu keadaan ketika debitur tidak dapat melakukan prestasinya kepada, yang disebabkan adanya kejadian yang berada di luar kuasanya, seperti tindakan alam, gempa bumi, banjir, longsor, dll. Di dalam hukum yang disebut force majeure adalah keadaan yang menyebabkan bahwa suatu hak atau suatu kewajiban dalam suatu perhubungan hukum tidak dapat dilaksanakan. ${ }^{20}$

\footnotetext{
18 Perselisihan hak adalah perselisihan yang timbul karena tidak dipenuhinya hak, akibat adanya perbedaan pelaksanaan atau penafsiran terhadap ketentuan peraturan perundang-undangan, perjanjian kerja, peraturan perusahaan, atau perjanjian kerja bersama. Perselisihan kepentingan adalah perselisihan yang timbul dalam hubungan kerja karena tidak adanya kesesuaian pendapat mengenai pembuatan, dan/atau perubahan syarat-syarat kerja yang ditetapkan dalam perjanjian kerja, atau peraturan perusahaan, atau perjanjian kerja bersama. Perselisihan pemutusan hubungan kerja adalah perselisihan yang timbul karena tidak adanya kesesuaian pendapat mengenai pengakhiran hubungan kerja yang dilakukan oleh salah satu pihak. Perselisihan antar serikat pekerja/serikat buruh adalah perselisihan antara serikat pekerja/serikat buruh dengan serikat pekerja/serikat buruh lain hanya dalam satu perusahaan, karena tidak adanya persesuaian paham mengenai keanggotaan, pelaksanaan hak, dan kewajiban keserikatpekerjaan.

${ }^{19}$ Zainal Asikin, Agusfian Wahab, Lalu Husni dan Zaeni Asyhadie. Op.Cit. hlm. 174. Lihat juga Soepomo, Hukum Perburuhan Bidang Pelaksanaan Hubungan Kerja, Cet. V, Djambatan, 1983, hlm. 115116.

${ }^{20}$ Bens22 HR Opinion, Aspek Pengupahan Dalam Merumahkan Pekerja pada Kondisi Covid-19, Peraduan Bekasi, 01 April 2020, di unduh pada tanggal 4 April 2020.
} 
Kondisi force majeure juga disebutkan Pasal 1244 dan 1245 KUHPerdata yang menegaskan bahwa suatu keadaan dimana tidak terlaksananya apa yang diperjanjikan karena hal-hal yang sama sekali tidak dapat diduga dan debitur tidak dapat berbuat apa-apa terhadap keadaan atau peristiwa yang timbul di luar dugaan tersebut. ${ }^{21}$

Sri Soedewi Masjchoen Sofwan menjelaskan bahwa Overmacht (keadaan memaksa) adalah keadaan dimana debitur sama sekali tidak mungkin memenuhi perutangan (absolute overmacht) atau masih memungkinkan memenuhi perutangan, tetapi memberikan pengorbanan besar yang tidak seimbang atau kekuatan jiwa di luar kemampuan manusia atau dan menimbulkan kerugian yang sangat besar (relative overmacht). ${ }^{22}$ Sedangkan Edy Sutrisno force majeure harus diartikan bahwa kegiatan operasional perusahaan tidak dapat berjalan sebagaimana mestinya sehingga pengusaha dan pekerja/buruh tidak dapat menjalankan kewajibannya masing-masing dikarenakan oleh keadaan yang tidak dapat dihindarkan atau diluar kemampuan manusia. Untuk menentukan keadaan-keadaan dimaksud sebagai keadaan force majure ukuranya adalah apakah keadaan dimaksud sesuatu yang tidak dapat dihindarkan dan diluar kemampuan manusia atau tidak. ${ }^{23}$

Keadaan memaksa dalam UUK masih kurang dan belum adanya aturan yang menjelaskan lebih lanjut terkait dengan keadaan memaksa atau force majeure tersebut. Pengertian keadaan memaksa atau force majeure biasanya merujuk pada tindakan alam (act of God), seperti bencana alam (banjir, gempa bumi, kerusuhan, pernyataan perang, dan sebagainya).

Covid-19 tidak terduga, tidak ada pihak yang mampu memprediksi apakah atau kapan Covid-19 dapat terjadi. PHK karena kondisi penyebaran Covid-19 jika dihubungkan dengan ketentuan yang ada dalam UUK, maka dapat dikaitkan dengan alasan force majure sebagaimana diatur Pasal 164 UUK yang menyebutkan bahwa :

1. Pengusaha dapat melakukan pemutusan hubungan kerja terhadap pekerja/buruh karena perusahaan tutup yang disebabkan perusahaan mengalami kerugian secara terus menerus selama 2 (dua) tahun, atau keadaan memaksa (force majeur), dengan ketentuan pekerja/buruh berhak atas uang pesangon sebesar 1 (satu) kali ketentuan Pasal 156 ayat (2), uang penghargaan masa kerja sebesar 1 (satu) kali ketentuan Pasal 156 ayat (3) dan uang penggantian hak sesuai ketentuan Pasal 156 ayat (4).

2. Kerugian perusahaan sebagaimana dimaksud pada ayat (1) harus dibuktikan dengan laporan keuangan 2 (dua) tahun terakhir yang telah diaudit oleh akuntan publik.

3. Pengusaha dapat melakukan pemutusan hubungan kerja terhadap pekerja/buruh karena perusahaan tutup bukan karena mengalami kerugian 2

${ }^{21}$ Rahmat S.S. Soemadipradja, Penjelasan Hukum Tentang Keadaan Memaksa (Syarat-syarat pembatalan perjanjian yang disebabkan keadaan memaksa/force majeure, (Jakarta : PT. Gramedia, 20100, hlm. 72.

22Sri Soedewi Masjchoen Sofwan, Hukum Perdata, Hukum Perutangan, Bagian A, (Yogyakarta, Seksi Hukum Perdata Fakultas Hukum Universitas Gadjah Mada, 1980) hlm. 20.

${ }^{23}$ Edy Sutrisno Sidabutar, Pedoman Penyelesaian PHK, (Tangerang: Elpress, 2007), hlm. 21. 
(dua) tahun berturut-turut atau bukan karena keadaan memaksa (force majeur) tetapi perusahaan melakukan efisiensi, dengan ketentuan pekerja/buruh berhak atas uang pesangon sebesar 2 (dua) kali ketentuan Pasal 156 ayat (2), uang penghargaan masa kerja sebesar 1 (satu) kali ketentuan Pasal 156 ayat (3), dan uang penggantian hak sesuai ketentuan Pasal 156 ayat (4).

Dari ketentuan tersebut di atas dapat diartikan bahwa PHK dapat dilakukan apabila perusahaan tutup dikarenakan keadaan memaksa yang disebabkan penyebaran covid-19 sehingga untuk dilakukan PHK sesuai ketentuan Pasal 164 UUK dipersyaratkan haruslah perusahaan tutup dan/atau melalukan efisiensi dengan terlebih dahulu melakukan langkah-langkah sebagaimana Surat Edaran Menteri Nomor SE907/MEN/PHI-PPHI/X/2004 tertanggal 28 Oktober 2004 yang isinya: Namun apabila dalam suatu perusahaan mengalami kesulitan yang dapat membawa pengaruh terhadap ketenagakerjaan, maka pemutusan hubungan kerja haruslah merupakan upaya terakhir setelah dilakukan upaya sebagai berikut: a). Mengurangi upah dan fasilitas pekerja tingkat atas misalnya tingkat manager dan direktur; b). Membatasi/menghapuskan kerja lembur; c). Mengurangi Jam Kerja; d). Mengurangi Hari Kerja; e). Meliburkan atau merumahkan pekerja/buruh secara bergilir untuk sementara waktu;f). Tidak atau memperpanjang kontrak bagi pekerja yang sudah habis masa kontraknya; g). Memberikan pensiun bagi yang sudah memenuhi syarat.

Ketentuan yang hampir sama juga terdapat dalam Putusan Mahkamah Konstitusi (MK) Nomor 19/PUU-IX/2011, tanggal 20 Juni 2012 menyatakan:

PHK hanya sah dilakukan setelah perusahaan tutup secara permanen dan sebelumnya perusahaan melakukan sejumlah langkah terlebih dahulu dalam rangka efisiensi sebagai berikut: (a) mengurangi upah dan fasilitas pekerja tingkat atas, misalnya tingkat manajer dan direktur; (b) mengurangi shift; (c) membatasi/menghapuskan kerja lembur; (d) mengurangi jam kerja; (e) mengurangi hari kerja; (f) meliburkan atau merumahkan pekerja/buruh secara bergilir untuk sementara waktu; (g) tidak atau memperpanjang kontrak bagi pekerja yang sudah habis masa kontraknya; (h) memberikan pensiun bagi yang sudah memenuhi syarat. Karena pada hakikatnya tenaga kerja harus dipandang sebagai salah satu aset perusahaan, maka efisiensi saja tanpa penutupan perusahaan dalam pengertian sebagaimana telah dipertimbangkan dalam paragraf tidak dapat dijadikan alasan untuk melakukan PHK. ${ }^{24}$

\section{Perlindungan Hukum Pemutusan Hubungan Kerja karena Covid-19}

Zaeni Assyhadie menjelaskan bahwa perlindungan pekerja dapat dilakukan baik dengan jalan memberikan santunan, maupun dengan jalan meningkatkan pengakuan hak-hak asasi manusia, perlindungan fisik dan sosial ekonomi melalui norma yang berlaku di perusahaan. ${ }^{25}$

24 Putusan Mahkamah Konstitusi (MK) Nomor 19/PUU-IX/2011, tanggal 20 Juni 2012

${ }_{25}$ Zaeni Asyhadie, Hukum Kerja : Hukum Ketenagakerjaan Bidang Hubungan Kerja, Edisi Revisi, Jakarta: PT. RajaGrafindo, 2008 ), hlm. 86. 
Perlindungan pekerja oleh negara akibat penyebaran Covid-19 merupakan merupakan hak konstitusional bidang ketenagakerjaan dan kesehatan yang secara tegas dijamin dalam UUD NRI Tahun 1945 dalam beberapa pasal terkait yaitu :

a. Pasal 27 ayat (2) menyatakan bahwa "Tiap-tiap warga negara berhak atas pekerjaan dan penghidupan yang layak bagi kemanusiaan."

b. Pasal $28 \mathrm{H}$ ayat (1), menyatakan “...setiap orang berhak hidup sejahtera lahir dan batin, bertempat tinggal, dan mendapatkan lingkungan hidup yang baik dan sehat serta berhak memperoleh pelayanan kesehatan..."

c. Pasal $28 \mathrm{H}$ ayat (2), menyatakan “...setiap orang berhak mendapat kemudahan dan perlakuan khusus untuk memperoleh kesempatan dan manfaat yang sama guna mencapai persamaan dan keadilan...".

d. Pasal $28 \mathrm{H}$ ayat (3) menyatakan bahwa "Setiap orang berhak atas jaminan sosial yang memungkinkan pengembangan dirinya secara utuh sebagai manusia yang bermartabat".

e. Pasal 34 ayat (2) menyatakan "Negara mengembangkan sistem jaminan sosial bagi seluruh rakyat dan memberdayakan masyarakat yang lemah dan tidak mampu sesuai dengan martabat kemanusiaan.

f. Pasal 34 ayat (1) menyatakan "Fakir miskin dan anak terlantar dipelihara negara". Selaras dengan UUD NRI Tahun 1945, perlindungan hukum juga ditegaskan kembali dalam UUK Pasal 4 huruf c, Pasal 5, Pasal 6, Pasal 11, Pasal 12, Pasal 31, Pasal 86 ayat (1), Pasal 88 ayat (1), Pasal 99 ayat (1) dan Pasal 104 ayat (1) dengan penjelasan sebagai berikut :

a. Pembangunan ketenagakerjaan bertujuan: memberikan perlindungan kepada tenaga kerja dalam mewujudkan kesejahteraan; dan

b. Setiap tenaga kerja memiliki kesempatan yang sama tanpa diskriminasi untuk memperoleh pekerjaan.

c. Setiap pekerja/buruh berhak memperoleh perlakuan yang sama tanpa diskriminasi dari pengusaha.

d. Setiap tenaga kerja berhak untuk memperoleh dan/atau meningkatkan dan/atau mengembangkan kompetensi kerja sesuai dengan bakat, minat, dan kemampuannya melalui pelatihan kerja.

e. Setiap pekerja/buruh memiliki kesempatan yang sama untuk mengikuti pelatihan kerja sesuai dengan bidang tugasnya.

f. Setiap tenaga kerja mempunyai hak dan kesempatan yang sama untuk memilih, mendapatkan, atau pindah pekerjaan dan memperoleh penghasilan yang layak di dalam atau di luar negeri.

g. Setiap pekerja/buruh mempunyai hak untuk memperoleh perlindungan atas: keselamatan dan kesehatan kerja; moral dan kesusilaan; dan perlakuan yang sesuai dengan harkat dan martabat manusia serta nilai-nilai agama. 
h. Setiap pekerja/buruh berhak memperoleh penghasilan yang memenuhi penghidupan yang layak bagi kemanusiaan.

i. Setiap pekerja/buruh dan keluarganya berhak untuk memperoleh jaminan sosial tenaga kerja. ${ }^{26}$

Menjadi sangat relevan pendapatnya Soepomo mengenai perlindungan pekerja sebagaimana banyak dikutip oleh penulis-penulis di bidang ketenagakerjaan, maka secara prinsip bahwa dalam kondisi penyebaran Covid-19 yang begitu cepat dan berbahaya, maka teori perlindungan pekerja dapat dilakukan dengan bentuk, Perlindungan Kesehatan Kerja, Perlindungan Keselamatan Kerja dan Perlindungan Upah Pekerja. ${ }^{27}$

Perlindungan kesehatan pekerja, Menteri Ketenagakerjaan Ida Fauziah telah mengeluarkan Surat Edaran (SE) No. M/3/HK.04/III/2020 tentang Perlindungan Buruh/Pekerja dan Kelangsungan Usaha dalam Rangka Pencegahan dan Penanggulangan Covid-19. Edaran yang ditujukan kepada seluruh gubernur itu meminta agar pemerintah daerah berupaya mencegah penyebaran dan penanganan kasus terkait Covid-19 di lingkungan kerja. Secara ringkas, peraturan tersebut meminta gubernur memerintahkan setiap pemimpin perusahaan di daerahnya untuk melakukan 3 hal pokok yaitu mengantisipasi penyebaran Covid-19 pada pekerja/buruh dengan tindakan pencegahan seperti perilaku hidup bersih dan sehat serta program Keselamatan dan Kesehatan Kerja (K3), membuat rencana kesiapsiagaan menghadapi pandemi Covid-19 dengan tujuan memperkecil risiko penularan di tempat kerja dan menjaga kelangsungan usaha dan mengambil langkah penanganan risiko terhadap pekerja/buruh atau pengusaha yang diduga terinfeksi Covid-19 sesuai standar penanganan Kementerian Kesehatan. ${ }^{28}$

Perlindungan keselamatan kerja, di tengah pandemi yang belum dapat diprediksi kapan berakhir, work from home (WFH) menjadi satu-satunya opsi untuk mencegah keadaan lebih buruk bagi karyawan maupun perusahaan. Karena itu, pemimpin perusahaan mesti memikirkan sistem WFH yang produktif. Meski kerja remote, perusahaan harus tetap dapat memantau jam kerja serta absensi karyawan. ${ }^{29}$ Masalah WFH di tengah wabah corona dapat dikaitkan dengan ketentuan Pasal 86 ayat (1) huruf a UUK di mana setiap pekerja/buruh mempunyai hak untuk memperoleh perlindungan atas keselamatan dan kesehatan kerja. ${ }^{30}$

${ }^{26}$ Lihat juga Abdul Khakim, Pengantar Hukum Ketenagakerjaan Indonesia Berdasarkan Undang-Undang No. 13 tahun 2003 tentang Ketenagakerjaan, Cet. II, (Bandung: PT. Citra Aditya Bhakti, 2007), hlm. 104-105.

${ }_{27}$ Zainal Asikin, Agusfian Wahab, Lalu Husni dan Zaeni Asyhadie, Op.Cit., hlm. 97. Selaina itu Abdul Khakim juga menjelaskan objek perlindungan tenaga kerja dalam UU No. 13 Tahun 2003 Tentang Ketenagakerjaan meliputi : perlindungan atas hak-hak dalam hubungan kerja, perlindungan hak-hak dasar pepekerja/buruh untuk berunding dengan pengusaha dan mogok kerja, perlindungan keselamatan dan kesehatan kerja, perlindungan khsusu bagi pekerja perempuan, anak-anak dan penyandang cacat, perlindungan upah, kesejahteraan dan jaminan social dan perlindungan atas hak pemutusan hubungan kerja.

${ }^{28}$ Radika K Cahyadi, Loc.Cit.

${ }^{29}$ Ibid.

${ }^{30}$ Bernadetha Aurelia Oktavira, Loc.Cit. 
Perlindungan Upah Pekerja, Jika terjadi PHK dalam masa penyebaran covid-19, maka Pasal 156 ayat (1) UU Ketenagakerjaan menegaskan bahwa dalam hal terjadi pemutusan hubungan kerja, pengusaha diwajibkan membayar uang pesangon dan atau uang penghargaan masa kerja dan uang penggantian hak yang seharusnya diterima. Berapa uang pesangon tergantung alasan yang digunakan. Jika Pasal 164 ayat (1) UUK maka uang pesangon sebesar 1 (satu) kali ketentuan Pasal 156 (2) uang penghargaan masa kerja sebesar 1 (satu) kali ketentuan Pasal 156 (3) dan uang penggantian hak sesuai ketentuan Pasal 156 (4) UUK. Dan jika alasan PHK menggunakan alasan Pasal 164 ayat (3) mendapatkan uang pesangon sebesar 2 (dua) kali ketentuan Pasal 156 (2) uang penghargaan masa kerja sebesar 1 (satu) kali ketentuan Pasal 156 (3) dan uang penggantian hak sesuai ketentuan Pasal 156 (4) UUK. Namun sekali lagi merujuk pada Pasal 151 UUK agar dihindari PHK dan selalu menciptakan hubungan kerja yang harmonis dan berkesinambungan. ${ }^{31}$

Untuk melakukan pencegahan terhadap dampak penyebaran Covid-19, Dinas Tenaga Kerja, Transmigrasi, dan Energi Provinsi DKI Jakarta sendiri telah menerbitkan Surat Edaran Dinas Tenaga Kerja, Transmigrasi dan Energi Provinsi DKI Jakarta Nomor 14/SE/2020 Tahun 2020 tentang Himbauan Bekerja di Rumah (Work From Home) menindaklanjuti Instruksi Gubernur Provinsi DKI Jakarta Nomor 16 Tahun 2020 tentang Peningkatan Kewaspadaan Terhadap Risiko Penularan Infeksi Corona Virus Disease (Covid-19). ${ }^{32}$

Namun apabila dalam proses PHK salah satu pihak tidak menerima, maka dapat diselesaikan dengan merujuk pada UU PPHI dengan tahapan mekanisme penyelesaian mulai dari Bipartit, Tripartit (Konsiliasi atau Arbitrase dan Mediasi) dan terakhir pengajuan gugatan ke Pengadilan Hubungan Industrial pada Kewenangan Pengadilan Negeri dimana perusahaan berada atau buruh bekerja. ${ }^{33}$

\section{KESIMPULAN}

Penyebaran Covid-19 dapat dikualifikasi sebagai kondisi force majeure sebagaimana diatur Pasal 164 ayat (1) UUK dengan mendasarkan pada keadaan memaksa, namun untuk melakukan PHK tetap mensyaratkan adanya kerugian dan

${ }^{31}$ Maimun, Hukum Ketenagakerjaan Suatu Pengantar, Cet. 2 (Jakarta: PT. Pradnya Paramitha, 2007), hlm. 103.

${ }^{32}$ Bernadetha Aurelia Oktavira, HukumOnline.com, Ketentuan Pelaksanaan Work From Home di Tengah Wabah Corona. Hukum Online, Jumat, 03 April 2020. Langkah-langkah pencegahan yang dapat diambil dikelompokkan menjadi tiga kategori

a. Perusahaan untuk sementara waktu dapat menghentikan seluruh kegiatan usahanya.

b. Perusahaan untuk sementara waktu dapat mengurangi sebagian kegiatan usahanya (sebagian karyawan, waktu, dan fasilitas operasional).

c. Perusahaan yang tidak dapat menghentikan kegiatan usahanya, mengingat kepentingan langsung yang berhubungan dengan pelayanan kesehatan, kebutuhan bahan-bahan pokok, dan bahan bakar minyak (BBM).

${ }^{33}$ Mekanisme Bipartit merupakan tahapan wajib yang harus dilakukan sebelum menempuh Tripartit baik melalui konsiliasi, arbitrase dan mediasi dengan menyesuaikan jenis perslisihan yang ada dan pilihan dari para pihak yang berselisih. 
perusahaan tutup dan/atau PHK dapat dilakukan ketentuan Pasal 164 ayat (3) UUK dengan alasan efisiensi dengan syarat perusahaan tertutup dengan terlebih dahulu dilakukan tindakan pendahuluan sebagaimana diatur Surat Edaran Menteri Nomor SE907/MEN/PHI-PPHI/X/2004 tertanggal 28 Oktober 2004 dan Putusan Mahkamah Konstitusi Nomor 19/PUU-IX/2011, tanggal 20 Juni 2012.

Perlindungan hukum pekerja pada masa penyebaran penyebaran Covid-19 telah dijamin dalam Pasal 27, 28H ayat (1), (2) dan (3), 34 ayat (1) dan (2) UUD NRI Tahun 1945 dan UUK.

Untuk itu disarankan kepada Perusahaan dan Pekerja melakukan langkahlangkah sebagai berikut: a). Melakukan komunikasi dengan tetap menjaga keharmonisan dan keberlangsungan hubungan kerja; b). Mentaati semua himbauan yang diterbitkan pemerintah sebagai upaya untuk melakukan pencegahan terhadap penyebaran Covid-19; c). Perusahaan menerapkan sistem kerja work from home dalam masa penyebaran Covid-19 sampai sudah dinyatakan bebas oleh pemerintah; d). Perusahaan mengikuti langkah-langkah yang ditentukan Surat Edaran Menteri Nomor SE-907/MEN/PHI-PPHI/X/2004 tertanggal 28 Oktober 2004 dan Putusan Mahkamah Konstitusi Nomor 19/PUU-IX/2011, tanggal 20 Juni 2012 sebelum melakukan pemutusan hubungan kerja; e). Untuk menghindari dampak adanya PHK, Pemerintah harus memenuhi hak-hak konstitusional warga negaranya sesuai amanat UUD NRI Tahun 1945 dan Peraturan Perundang-Undangan.

\section{REFERENSI:}

Buku-Buku

Amiruddin dan Zainal Asikin, Pengantar Metode Penelitian Hukum, Jakarta: RajaGrafindo, 2016.

Asikin, Zainal, Agusfian Wahab, Lalu Husni dan Zaeni Asyhadie, Dasar-Dasar Hukum Perburuhana, Jakarta : RajaGrafindo Persada, 2008.

Asyhadie, Zaeni, Hukum Kerja : Hukum Ketenagakerjaan Bidang Hubungan Kerja, Edisi Revisi, Jakarta : PT. RajaGrafindo, 2008..

Husni, Lalu, Pengantar Hukum Ketenagakerjaan Indonesia, Edisi Revisi, Jakarta: RajaGrafindo, 2003.

Khakim, Abdul, Pengantar Hukum Ketenagakerjaan Indonesia Berdasarkan UndangUndang No. 13 tahun 2003 tentang Ketenagakerjaan, Cet. II, Bandung : PT. Citra Aditya Bhakti, 2007.

Maimun, Hukum Ketenagakerjaan Suatu Pengantar, Cet. 2, Jakarta: PT. Pradnya Paramitha, 2007.

Marzuki, Peter Mahmud, Penelitian Hukum, Cet. I, Jakarta : Prenada Media, 2008.

Sidabutar, Edy Sutrisno, Pedoman Penyelesaian PHK, Tangerang : Elpress, 2007.

Soemadipradja, Rahmat S.S. Penjelasan Hukum Tentang Keadaan Memaksa (Syaratsyarat pembatalan perjanjian yang disebabkan keadaan memaksa/force majeure, Jakarta : PT. Gramedia, 2010.

Soepomo, Hukum Perburuhan Bidang Pelaksanaan Hubungan Kerja, Cet. V, Djambatan, 1983. 
Sofwan, Sri Soedewi Masjchoen, Hukum Perdata, Hukum Perutangan, Bagian A, Yogyakarta, Fakultas Hukum Universitas Gadjah Mada, 1980.

Soekanto, Soerjono dan Sri Mamudji, Penelitian Hukum Normatif Suatu Tinjauan Singkat, Jakarta, PT. RajaGrafindo, 2007.

Susanti, Diah Octorina dan A'an Effendi, Penelitian Hukum (Legal Research), cetakan 1 Jakarta: Sinar Grafika, 2014.

\section{A. Peraturan Perundangan}

Indonesia, Undang-Undang Dasar Negara Rpublik Indonesia Tahun 1945. Undang-Undang No. 13 tahun 2003 tentang Ketenagakerjaan Undang-Undang No. 2 Tahun 2004 tentang Penyelesaian Perselisihan Hubungan Industrial, LNRI No. 6, Tahun 2004.

Instruksi Gubernur Provinsi DKI Jakarta Nomor 16 Tahun 2020 tentang Peningkatan Kewaspadaan Terhadap Risiko Penularan Infeksi Corona Virus Disease (COVID-19) Surat Edaran Dinas Tenaga Kerja, Transmigrasi dan Energi Provinsi DKI Jakarta Nomor 14/SE/2020 Tahun 2020 tentang Himbauan Bekerja di Rumah (Work From Home).

\section{B. Putusan Pengadilan}

Putusan Mahkamah Kosntitusi Nomor 19/PUU-IX/2011, tanggal 20 Juni 2012

\section{Jurnal/Artikel}

Bayu Hermawan, Legislator Ingatkan Dampak Corona Jangan Sampai Sebabkan PHK, Republika.co.id, Senin 09 Mar 2020 18:13 WIB di unduh pada tanggal 4 April 2020.

Bens22 HR Opinion, Aspek Pengupahan Dalam Merumahkan Pekerja pada Kondisi Covid-19, Peraduan Bekasi, 01 April 2020, di unduh pada tanggal 4 April 2020.

Bernadetha Aurelia Oktavira, HukumOnline.com, Ketentuan Pelaksanaan Work From Home di Tengah Wabah Corona. Hukum Online, Jumat, 03 April 2020

Bimo Prasetio dan Mohamad Toha Hasan, Dapatkah Perusahaan Melakukan PHK Karena Kerugian Akibat Pandemi Covid-19? bplawyers.co.id, 1 April, 2020. Dapat dilihat ulasan lengkapnya di https://bplawyers.co.id/2020/04/01/dapatkah-perusahaan-melakukan-phkkarena-kerugian-akibat-pandemi-covid-19/ di unduh pada tanggal 4 April 2020.

Buana, Dana Riksa, "Analisis Perilaku Masyarakat Indonesia dalam Menghadapi Pandemi Virus Corona (Covid-19) dan Kiat Menjaga Kesejahteraan Jiwa," Salam: Jurnal Sosial dan Budaya Syar-i, Volume 7, No. 3 (2020).

jpnn.com, Jumlah Buruh Terkena PHK di Jakarta akibat Corona, Lumayan Banyak, Sabtu, 04 April 2020 - 18:17 WIB

Yunus, N.R.; Rezki, Annissa. "Kebijakan Pemberlakuan Lock Down Sebagai Antisipasi Penyebaran Corona Virus Covid-19," Salam: Jurnal Sosial dan Budaya Syar-i, Volume 7, No. 3 (2020). 